\title{
Unfair Competition in the Field of Intellectual Property Rights: Analyzing Concepts, Acts of Unfair Competition and Laws
}

\author{
Yongyeh Ngalim Elizabeth ${ }^{1}$, Lu Ming Yu ${ }^{1}$, Dagadu Prince Palmer ${ }^{2} \&$ Bright Anyomi $^{3}$ \\ ${ }^{1}$ School of Law and Economic, Zhengzhou University, Zhengzhou, China \\ ${ }^{2}$ School of Law, Xiamen University, China \\ ${ }^{3}$ School of Life Sciences, Henan University, Kaifeng, China. \\ Correspondence: Yongyeh Ngalim Elizabeth, School of Law and Economic, Zhengzhou University, Zhengzhou, \\ Henan, China. Tel: 183-3844-1271. E-mail: yongyehelizabeth97@gmail.com
}

Received: January 5, 2021

Accepted: February 16, 2021

Online Published: March 19, 2021

doi:10.5539/jpl.v14n3p44

URL: https://doi.org/10.5539/jpl.v14n3p44

\begin{abstract}
This study aims to analyze Unfair Competition in the field of Intellectual property rights. This research seeks to explore and show how the concept of unfair Competition interferes in the area of intellectual property rights. Furthermore, we have investigated how competition law and intellectual property rights interfere with each other. The research evaluates unfair competition practices in the scope of intellectual property rights, referring to specific international laws directly related to each course. Finally, it examines the regulatory system that governs these sectors. Reference is made particularly to the Chinese Anti-Unfair Competition Law and other international laws on trademark practices. As far as the study's methodology is concerned, qualitative data analysis is applicable alongside with comparative legal method for analyzing "de lege lata" and "de lege feranda" situations in a range of the concluded topic. The study finds out that Unfair Competition in the domain of Intellectual Property rights involves actions by an operator that infringe the legislation's rules, harm operators' legitimate rights and interest on the market, thereby threatening socio-economic order. The study concluded that Unfair Competition acts in the field of Intellectual Property rights (like Industrial espionage, infringement of trade secrets, trademark infringement) impede innovation, stifle, and affect Competition in the real market. And the occurrence of these Unfair Competition practices is common, even though there are existing legal frameworks that regulate this sector. The research reveals an international regulatory system such as the Paris Convention 1883, the Patent Act 1977, and the Espionage Act 1996 have specific and statutory laws that target unfair competition practices. The Chinese Anti-Unfair Competition Act 1993 forbids unfair Competition in intellectual property rights and defends operators and citizens from unfair competition practices. The study also deduces that the existing legal framework regulating this sector is practical to a small extent because these Unfair Competition Practices are still very much detectable in the trade sector. As most legal frameworks dwell on civil liabilities instead of criminal penalties, operators can easily violate the law by relying on whether they can afford the civil penalties. There are recent amendments to adjust and adapt to the evolution of patterns and daily market innovations (Example: Amendment of the Chinese Anti-Unfair Competition Law in 2003). We concluded the study by bringing in suggestions and recommendations. Qualitative research methodology applies to the following article.
\end{abstract}

Keywords: unfair competition, intellectual property rights

\section{Introduction}

Competition law promotes and seeks to maintain market competition to a certain degree by regulating, detecting, and punishing anti-competitive practices exercised by companies or other business organizations. Competition law authorities implement competition law policies through private and public enforcement. Competition law is referred to as antitrust law in the European Union. Lastly, Competition also stabilizes the market condition by regulating monopoly and unfair business practices.

Intellectual property rights refer to rights given to a person or a group of people over the creation of their minds or an invention. The freedom obtained is exclusive ownership, use, and possession of the trademark name or design. Intellectual property rights give a person or a company exclusive right to use its plans and ideas or intangible assets without worry of rivalry, at least for a specific period. Intellectual property rights can include copyrights, patents, 
trademarks, and trade secrets, to name a few.

\section{Literature Review}

The researchers diligently conducted this research bearing in mind that several researchers have made research and studies about Unfair Competition in the area of Intellectual Property rights. However, there is no existent research that has been made in this domain that has directly addressed Unfair Competition in the field of Intellectual Property rights: analyzing concepts, Unfair Competition acts, and laws. Therefore, there is no existing literature review that directly analyzes Unfair Competition in the field of Intellectual Property rights and makes particular reference to concepts, Unfair Competition acts, and laws. Nevertheless, there is a literature review and data on Unfair Competition, protection against Unfair Competition, and other studies that provide us with some literature review in this domain.

Firstly, Vivien Chan (2020) argues that article 2 of the Chinese Anti-Unfair Competition Law plays a vital role in curbing new types of unfair competition acts. According to the Chinese Anti-Unfair Competition Law (AUCL), business operators must adhere to the general principle of voluntary participation, equality, integrity, and fairness in the production and business operation sectors. With the help of cases, this article's authors illustrate how the Chinese AUCL is implemented on other unfair competition infringements in China to deal with Intellectual Property law's loopholes. ${ }^{1}$ The Paris Convention (1883) addresses Unfair Competition in article 10 bis of the Convention, and it is explicitly applicable to member countries. Member countries of the Paris Convention are obligated to ensure that citizens of those countries enjoy sufficient protection against unfair competition practices. Thereby promotes a fair-trade atmosphere and a certain level of Competition that is stable and conducive for market operations and businesses, thereby enabling the market's economic efficiency and protecting consumers. However, Tim W. Dornis (2017), author of the book Trademark and Unfair Competition Conflicts, presents the historical-comparative, doctrinal, and economic aspects of trademark and unfair competition conflicts law.

\subsection{Methodoloy}

A comparative legal method is used to analyze the "de lege lata" and "de lege feranda" situation in the solved topic's scope. This research is analytical, descriptive, and comparative. As far as the research approach is concerned, qualitative data analysis is applied to conduct this research. Both primary and secondary sources have been used to carry out the study.

\section{Competition Law and Intellectual Property Rights: Analysis of How They Interact}

Furthermore, during this research work, we discovered an intersection between competition law and Intellectual property rights. Intellectual Property Rights give exclusive usage and ownership to an individual for their invention. But if he/she uses this right to stifle Competition, Anti-monopoly or competition law comes in to break and control this right and freedom in cases the inventor may have used this right to exercise a dominant position in the market.

Intellectual property concerns the right to exclusivity over the economical use of the artistic mind fruits (invention) and such signs used by business owners. This right, conferred to the creator, gives them the freedom to exploit this invention. If an operator or a company uses his exclusive right to exercise an anti-competitive act thus, stifling Competition in the market at this point, Competition law comes in to intervene and make sure that this anticompetitive practice is punishable according to the law. Thus, at this level, Competition law and Intellectual Property Rights conflict. Competition law enforces sanctions against Unfair Competition practices; therefore, these two laws complement each other. Intellectual property licenses can improve economic efficiency².

Besides, after providing a brief analysis on the concept of competition law and intellectual property rights and exploring how these doctrines interact or overlap, we shall move on to our focal point of unfair Competition in the area of intellectual property rights.

\section{Unequal Competition in the Area of Intellectual Property Rights}

The doctrine of Unfair Competition in intellectual property rights derives from the fact that there is an illegal, deceptive trade that legislation, rule, or common law forbid. Unfair Competition is a term that refers to fraudulent or unlawful Competition in trade and commerce.

Unfair Competition can be through false, fraudulent, or unethical commercial conduct like predatory pricing, counterfeiting or imitation, dumping, misleading advertisement, trademark, or trade secret infringement. Some

\footnotetext{
${ }^{1}$ Vivien Chan "The Anti-Unfair Competition law and its impact on I.P. cases in China" (April 16, 2020), China PRC, Managing I.P. Magazine www.managingip.com

${ }^{2}$ Competition Law Tutorial, 21 Century Civil and Commercial Law Series Textbook, page 192, Second Edition, by Lu Ming Yu, Published by the Chinese People University Press.
} 
other actions that fall under Unfair Competition's concept include infringement of patents, trademarks, copyrights, Wrongful appropriation of trade names, trade dress and trade secrets, and actions for publication of defamatory, false, or misleading representations.

It is a phenomenon (Unfair Competition) that, for some reason, occurs in the domain of intellectual property rights, including the fact that a consumer economy facilitates and supports Competition between industrial and commercial organizations. Competitors, industrial magnates, and corporations are out to succeed and make a massive amount of profit. Some operators quench their search for success by using malicious means such as misleading the public to the detriment of an entrepreneur. Some companies or individuals do not want to go through the process or stress of inventing ideas and trademarks. So, they prefer to use already registered patents and trademarks illegally, and it facilitates patent and trademark registration and all other procedures involved.

We discovered that most unfair competition practices are already regulated by most countries' international and national laws during this research. However, these practices persist and are more evident in the $21^{\text {st }}$ century, especially with the rapid technological advancement.

\section{Acts of Unfair Competition according to Paris Convention 1883}

Unfair Competition acts of rivalry are strongly associated with intellectual property. The Paris Convention (1883) is enforceable in countries that are members of this Convention, and each country's national laws that govern this field is also applicable. For Unfair Competition, Article 10 bis of the Paris Convention is explicitly relevant ${ }^{3}$.

(1) To union countries are obligated to ensure that citizens of those countries enjoy sufficient protection against unfair competition Article 10 bis of the Paris Convention Article 10 bis (1).

(2) An act of Unfair Competition, Article 10 bis (2) of the Paris Convention, constitutes Competition contrary to ethical standards in industrial or economic matters.

(3) Article 10 bis (3) shall be excluded as follows4:

1. Acts of a kind that can cause conflict by whatsoever with a competitor's established, established products, or industrial or commercial practices.

2. During a trade, false accusations can discredit the state's industrial or commercial practices, the products, or competitors.

3. The signs or claims used in the course of commerce are liable to deceive the public as to the existence, method of production, specifications, suitability for their intent, or the quality of the products.

\section{Unfair Competition Actions That Damage Goodwill}

\section{a- Trademark Infringement}

Trademark infringement is an act or activity that causes doubt about another's enterprise or practices during manufacturing or business activities. An Act of Unfair Competition constitutes an act, especially concerning the goods or services provided by such an undertaking. Trademark misuse happens when the brand on the market is used by another person who confuses the public.

A registered trademark is a right of copyright in which the owner receives exclusive permission to use the trademark. Article 8 of the Paris Convention of 1883 states that a brand name is protected in all the Union countries, whether it is part of a trademark without the need to file or register.

Section 5(3) of the Law Against Unfair Competition of the People's Republic of China describes the Trademark Trespass as an activity to use, without authorization, the corporate name or personal name of the other person on its goods, which causes people to misinterpret them in the interests of another person. There is a guiding case in China on trademark infringement, which falls under an unfair competition dispute. Suremoov Automotive Technology Company Limited v. Tianjin Xiaomuzhi Car Servicing and Repairs Services Co. Case No. 30, LAN Jianjun and Hangzhou Inc. Ltd et al.

\section{Acts Damaging Reputation}

\section{b-Patent Violation}

Patent infringement means the manufacture, use, distribution, or import of a patented product or method without the patent proprietor's consent. Article 60, 1(1) of the Patents Act 1977 (as amended) Article 4ter of the Paris

\footnotetext{
${ }_{3}^{3}$ Paris Convention for the Protection of Industrial Property March 20, 1883, Article 10

${ }^{4}$ Paris Convention for the Protection of Industrial Property March 20, 1883, Article 10
} 
Convention states that inventors' novel inventions shall receive patent certificates; the patentee must be mentioned in the patent certificate ${ }^{5}$. In a case where there is a patent violation, a patentee has the right to a court argument.

However, there are exceptions to Article 60, 1(1) of the Patents Act. Under Section 60(5)(a) of the Patent Act 1977 (as amended), there is a list of defenses against patent infringement ${ }^{6}$. Also, if it is for individual use and noncommercial reasons, it is appropriate to use a patent ${ }^{7}$.

Section 64 of the Patents Act 1977 grants third parties the ability to continue actions that would otherwise infringe a patent if such an act establishes itself before enacting (or before the coming into force of) the legislation. The deed must have been executed in good faith ${ }^{8}$. The case on patent violation is related to China, guiding case No. 20 Shenzhen Siruiman Fine Chemicals Co., Ltd v. Shenzhen Kengzi Water Supply Co., Ltd and Shenzhen Kangtalian Water Supply Co., Ltd. The above case is a Patent Infringement Dispute.

\section{c-Infringement of Trade Secrets}

Firstly, a trade secret means technological knowledge and organizational information that is not known to the public. It can provide economic gains to the rights holders and has practical applicability, and the rights holder has taken action to keep it confidential. Consequently, infringement of a trade secret by extracting trade secrets from the rights holders by cheating, threatening profits, returning coercion, or other improper means. Under Article 10 of the Law on unfair Competition of the People's Republic of China, the operator shall in no way take the following standards to infringe trade secrets:

(1) Extracting trade secrets from the rightsholders through cheating, threatening profits, restoring coercion or, other unethical means.

(2) Disclosure. Use or authorize others to use the rights holders' trade secrets, employing the subsection mentioned earlier (1).

(3) Revealing, using, or authorizing someone to use the trade secrets acquired by violating the agreement by failing to comply with the duty of the holder of the rights to keep the trade secrets private 9 .

In compliance with Article 10(1), (2), and (3), when a third party obtains, uses, or discloses the trade secrets of another, these acts shall be considered as a violation of the trade secrets of others. And if it is clear that the third party has or should have been entirely aware of the criminal activities alluded to in the preceding paragraph ${ }^{10}$.

\section{c-Industrial/Economic Espionage}

Industrial Espionage is when an employee discloses a company's confidential information to another company or people. It may be a secret of a company; it could involve producing its goods or maybe packaging. To be called a secret, it must have been by the owner of the trade secret.

In Argentina, for example, Section 85 of the Labor Law (Law number 20,744) states that employees have a loyalty obligation per the duties they carry out ${ }^{11}$. Employees may not disclose confidential information they have access to because of their activity.

According to the International Espionage Act of 1996 Section 1831(a), Economic espionage in general, is anyone, meaning or believing that the crime would profit any foreign nation, foreign instrument, or foreign agent, knowingly:

(1) Gives away, brings away or conceals, or obtains a trade secret utilizing theft, cunning, or deceit, or without authorization;

(2) Clones, duplicates, models, illustrations, images, scans, uploads, alters, kills, photocopies, copies, transmits, delivers, gives, emails, shares, or conveys a trade secret without authorization ${ }^{12}$;

(3) Collects, purchases, or possesses a trade secret, knowing the same to have been stolen or appropriated, gained

\footnotetext{
${ }^{5}$ Patents Act 1977 (as amended) (2018) Intellectual Property Office, www.gov.uk accessed 20 November 2020.

${ }^{6}$ Patents Act 1977 (as amended) (2018) Intellectual Property Office, www.gov.uk accessed 20 November 2020.

7 Patents Act 1977 (as amended) (2018) Intellectual Property Office, www.gov.uk accessed 20 November 2020.

${ }^{8}$ Law Against Unfair Competition of the People's Republic of China September 2, 1993, Article 4 bis (1).

${ }^{9}$ Law Against Unfair Competition of the People's Republic of China September 2, 1993, Article 4 bis (1).

${ }^{10}$ Law Against Unfair Competition of the People's Republic of China September 2, 1993, Article 4 bis (1).

${ }^{11}$ Intellectual Property, Industrial Espionage, and the Future of the Military Diffusion, by Robert Farley, March 19, 2015. www.cipscepi.ca/2015

${ }^{12}$ Intellectual Property, Industrial Espionage, and the Future of the Military Diffusion, by Robert Farley, March 19, 2015. www.cipscepi.ca/2015
} 
or transformed without the authorization;

(4) Attempts to commit any of the crimes mentioned in any of paragraphs (1) to (3);

(5) Collusion with one or more other persons to commit an offense referred to in either of the provisions of paragraph (1) (3). One or more of such persons shall commit any conduct with the intent of plotting, and, according to subsection (b) of the Economic Espionage Act, a fine of not more than $\$ 500,000$ or incarceration of not more than 15 years or both ${ }^{13}$.

However, digitalizing information has made Intellectual Property rights more available to spies, particularly patents and trade secrets. Patent offices have become more functional, digital documents have expanded in reach, and companies have made more of their business online. Thus, this is one of the reasons why industrial espionage is so simple and so widespread.

\section{Legal framework in China for Unfair Competition}

Every country has many laws that aim at regulating Competition. China has several laws that aim at promoting good competition practices, but a particular focus will be made on the Ant-Unfair Competition Law on Trademark Practice. This law was enacted in the year 1993, and China only recently amended the law in 2018. This amendment law has been approved by the Standing Committee of the National People's Congress on November 4, 2017, and entered into force on January 1, 2018 ${ }^{14}$.

The amendment had a significant impact on trademark practice. Firstly, the removal of clauses 5(1) and 2(1) avoids duplication with China's Trademark Law ${ }^{15}$. The Trademark Law at the same time regulates violations outlined in clauses 5(1) and 2(1) of the previous Anti- Unfair Competition Law, so the clauses are taken to avoid overlapping applications of the law ${ }^{16}$.

Clause 5 of the previous Anti-Unfair Competition Legislation established that "any business owner shall not use any of the following unfair ways of carrying out transactions during a business venture and causing harm to market riders: (1) counterfeiting the registered trade name of an individual."

If a business owner counterfeits another registered trademark, uses the name, or gives authorization to another corporation, counterfeits or fraudulently uses quality symbols such as identification symbols and emblems of wellknown and high-grade products. Alters the source of products and allows untruthful statements that are deceptive to the grade of the commodities. Clause 21 provides that he/she is sanctionable under the Trademark Law of China and the Product Quality Law of China. The previous overlap between these clauses and the Trademark Law caused inconvenience for intellectual property (I.P.) owners seeking protection on the Anti-Unfair Competition Law grounds. Their removal has, therefore, streamlined the legal process.

Besides, by widening the scope of the concept of I.P., the second law allows for wider coverage and protection of I.P., for example, about trademarks and trade names. Trade dress and trade names are discussed for the first time in Clause 6, which specifies that companies shall not perform such acts of misunderstanding to confuse customers. A number of new terms such as "trade name", "social organization name ", pseudonym", "stage name", "website name", and "webpage"17 have been defined. The addition of these terms, which represents a major step forward for China, illustrates that new terms that emerged in recent landmark cases can drive Chinese trademark law changes. China's AUCL is a powerful supplement to the specific intellectual property laws. It has reinforced protection against unauthorized use of brands, product packaging, store design, business practice, and trade secrets.

Other International legal frameworks and treaties that regulate this sector include the World International Property Organization (WIPO), World Trade Organization (WTO), and the TRIPS.

\section{Conclusion}

Unfair Competition in IPR is a concept and doctrine that is overly complex. It has become quite common to find actions considered as unfair practices in the market sector. The elaboration of stricter or stringent laws to regulate

\footnotetext{
${ }_{13}$ Economic Espionage Act of 1991, Section 1831 (b)

${ }^{14}$ An Article on the Impact of the Amended Anti-Unfair Competition Law on Trademark Practice, by Nikita Xue, www.inta.org/INTABulletin. Vol. 73 No. 9, May 15, 2018.

15 An Article on the Impact of the Amended Anti-Unfair Competition Law on Trademark Practice, by Nikita Xue, www.inta.org/INTABulletin. Vol. 73 No. 9, May 15, 2018.

${ }_{16}$ An Article on the Impact of the Amended Anti-Unfair Competition Law on Trademark Practice, by Nikita Xue, www.inta.org/INTABulletin. Vol. 73 No. 9, May 15, 2018.

17 An Article on the Impact of the Amended Anti-Unfair Competition Law on Trademark Practice, by Nikita Xue, www.inta.org/INTABulletin. Vol. 73 No. 9, May 15, 2018.
} 
this sector will assist IPR owners and protect consumers and help in one way or the other to curb down the growing trend of unfair competition practices in our modern world, especially with the ever-increasing technology. Also, most laws only provide civil liability. This makes infringers careless. If there are more and more criminal liabilities in a crime concerning unfair Competition, these practices will undoubtedly lessen in their numbers.

Moreover, enacting more stringent laws against unfair Competition in intellectual property rights will do an excellent job for the business sector. It will also protect the consumer financially and the health of consumers. Implementing anti-competitive Laws against unfair competition practices will also help the owners of business enterprises and inventors do business in a fair environment and play legally, thereby protecting all parties' rights. Enacting Laws will assist significantly in the economic sector by ensuring economic efficiency. Some legal experts say that fair Competition sustains and provides economic efficiency. The dream of every country is to have a strong economic power; Joseph A. Schumpeter rightly stated, "the sovereignty of a country is determined from how strong its economy is or from how its economy is fairing." Thus, each state must ensure fair Competition in its market to secure and sustain economic growth.

- Also, there are some limitations to the protection of some IPR. Such as geographical limitations on the protection of patents. Patents are geographically protected. Thus, it makes it easy for someone in another country to use another one's patent with ease and without the owner having the right or capacity to prosecute him/ her.

- Laws and legal principles have limitations, and as law students, professors, legal experts, and lawyers, we need to realize that some of these limitations may have a negative effect. We highly recommend that this section of intellectual property law be revised and updated to account for cases in which a company's patent is used in a country where the patent is not registered. The perpetrator should be charged and prosecuted for his behavior.

\section{References}

Barry, J. R., \& Angus, M. C. (2014). Competition Law and Policy in the E.C. and U.K. Routledge-Cavendish. https://doi.org/10.4324/9781315848532

Farley Robert, Intellectual Property, Cyber Espionage, and Military Diffusion. (2016). Global Security and Intelligence Studies, 1. https://doi.org/10.18278/gsis.1.2.2

Gary, H. (1997). Competition Policy, and Intellectual Property Rights. Organization for Economic Development (OECD). https://doi.org/10.2139/ssrn.141080

Graeme, B. D., \& Mark, D. J. (2014). Trademark and Unfair Competition. https://doi.org/10.4337/9781784713294

Haines, C. G. (1919). Efforts to define Unfair Competition. Yale Law Journal Company, Inc, 29, 3, https://doi.org/10.2307/786890

Joseph, A. S. (1934). The Theory of Economic Development. Cambridge, Mass.: Harvard University Press.

Lu, M. Y. (2015). Competition Law Tutorial, Civil and Commercial Law Series (2nd ed.). Beijing, Chinese People University Press.

Margaret, D.-W. (2013a). Patents Act 1977. Core Statutes on Intellectual Property. https://doi.org/10.1007/978-1137-35471-6_2

Margaret, D.-W. (2013b). Paris Convention for the Protection of Industrial Property. Core Statutes on Intellectual Property. https://doi.org/10.1007/978-1-137-35471-6_5

Naman, M. (2019). Conflict Between Intellectual Property Law and Competition Law: Critical and Comparative Analysis. Retrieved from www.mondaq.com

Paris Convention. (1883).

People's Republic of China Antitrust, Trade Regulation \& Unfair Competition Law. (1993). Dataset published in Foreign Law Guide. https://doi.org/10.1163/2213-2996_flg_com_052013

Recent cases on Anti-Unfair Competition Law in China and copyright infringement. Ming Ho Publications Co., Ltd and Perfect World (Beijing) Software Co., Ltd. V Firevale Internet Technology Co., Ltd., Beijing Kunlun Lexiang Network Technology Co., Ltd. 92018 Beijing Civil Final No.226. Retrieved from www.managingip.com

The Economic Espionage Act of 1996. (1997). Competitive Intelligence Review, 8. https://doi.org/10.1002/(sici)1520-6386(199723)8:3<4::aid-cir3>3.0.co;2-1

The Federal Trade Commission Act. (1914). Published in the dictionary of Marketing Communications. https://doi.org/10.4135/9781452229669 
The Federal Trade Commission. (1932, December 31). What is Unfair Competition? Retrieved from https://10.7312/blai93462-004

The Implementation of Trademark Policy in China. (2019). Intellectual Property Rights in China. https://doi.org/10.9783/9780812295702-007

Thomas, A. H., Thomas, M. J., \& David, J. T. (1993). Antitrust, Innovation, and Competitiveness. Southern Economic Journal, 60(2), 516. https://doi.org/10.2307/1060105

Tim, W. D. (2017). Trademark and Unfair Competition Conflicts. Cambridge University Press. https://doi.ord?10.1017/9781316651285

U.S. Department of Justice \& Federal Trade Commission, Antitrust Guidelines for the Licensing of Intellectual Property, Issued by U.S. Department of Justice, and the Federal Trade Commission. (2017, January 12).

Vivien, C. (2020, April 16). The Anti-Unfair Competition law and its impact on I.P. cases in China. China PRC, Managing I.P. Magazine. Retrieved from www.managingip.com

Xue, N. (2018). Impact of the Amended Anti-Unfair Competition Law on Trademark Practice. China INTA Bulletins Committee - Asia-Pacific Subcommittee, 73(9).

\section{Copyrights}

Copyright for this article is retained by the author(s), with first publication rights granted to the journal.

This is an open-access article distributed under the terms and conditions of the Creative Commons Attribution license (http://creativecommons.org/licenses/by/4.0/). 